\title{
A "critical" climatic evaluation of last interglacial (MIS 5e) records from the Norwegian Sea
}

\author{
Henning A. Bauch¹ \& Helmut Erlenkeuser ${ }^{2}$ \\ 1 Mainz Academy of Sciences, Humanities and Literature, c/o Leibniz Institute of Marine Sciences, University of Kiel ,Wischhofstrasse 1-3, DE-24148 \\ Kiel, Germany. \\ 2 Leibniz Laboratory for Radiometric Dating and Stable Isotope Research, University of Kiel, Max-Eyth-Strasse 11, DE-24098 Kiel, Germany
}

\author{
Keywords \\ Holocene; last interglacial; Nordic seas; \\ palaeoceanography; planktic foraminifers; \\ stable isotopes.

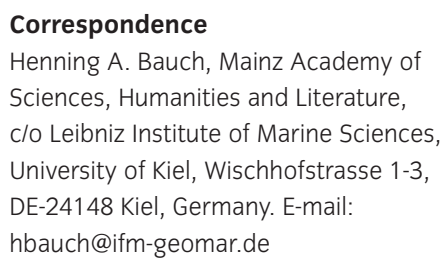

\begin{abstract}
Sediment cores from the Norwegian Sea were studied to evaluate interglacial climate conditions of the marine isotope stage 5e (MIS 5e). Using planktic forminiferal assemblages as the core method, a detailed picture of the evolution of surface water conditions was derived. According to our age model, a steplike deglaciation of the Saalian ice sheets is noted between ca. 135 and 124.5 Kya, but the deglaciation shows little response with regard to surface ocean warming. From then on, the rapidly increasing abundance of subpolar forminifers, concomitant with decreasing iceberg indicators, provides evidence for the development of interglacial conditions sensu stricto (5e-ss), a period that lasted for about $9 \mathrm{Ky}$. As interpreted from the foraminiferal records, and supported by the other proxies, this interval of 5e-ss was in two parts: showing an early warm phase, but with a fresher, i.e., lower salinity, water mass, and a subsequent cooling phase that lasted until ca. 118.5 Kya. After this time, the climatic optimum with the most intense advection of Atlantic surface water masses occurred until ca. 116 Kya. A rapid transition with two notable climatic perturbations is observed subsequently during the glacial inception. Overall, the peak warmth of the last interglacial period occurred relatively late after deglaciation, and at no time did it reach the high warmth level of the early Holocene. This finding must be considered when using the last interglacial situation as an analogue model for enhanced meridional transfer of ocean heat to the Arctic, with the prospect of a future warmer climate.
\end{abstract}

As a result of ongoing global warming, the polar Northern Hemisphere is considered to be the region on Earth for which large-scale environmental changes are expected within the near future. At present, this environment undergoes particularly extreme seasonal variations in temperature-sensitive processes: for instance, the variation in thickness and lateral extent of sea ice in the Arctic Ocean, which causes feedback mechanisms on atmospheric and oceanic circulations well beyond the polar realm itself. Whereas the heat balance dominates Arctic environments on a seasonal basis, variations in the mass input of relatively warm Atlantic surface water into the Arctic Ocean is a crucial factor on longer, centennial to millennial timescales.

Depending on the particular region, it has been shown that the Arctic and sub-Arctic region was warmer during the early Holocene (11-7 Kya) than later on, a situation partly induced by high insolation forcing. To put the Holocene (i.e., the past ca. 11 Kya), the present-day and some future aspects of the northern polar realm into a longer term climatic perspective, evaluating past conditions with environmental constraints similar to the current warm period is a reasonable measure. Relevant palaeo situations are easily found in deep-sea archives of the late Quaternary. The last interglacial period, marine isotope stage 5e (MIS 5e; some $125 \mathrm{Kya}$ ), is often suggested as representing a suitable candidate for such a climate analogy study on the global scale (e.g., Kukla $\delta$ Went 1992), as well as on northern, regional scales (e.g., Bauch et al. 1996; Fronval \& Jansen 1997). Somewhat in accordance with a higher level of insolation, investigations have indeed indicated that subpolar northern latitudes during MIS 5e experienced higher temperatures on land, and in the surface of the oceans, than have ever 
been found for the Holocene (e.g., Bauch \& Kandiano 2007). For the Arctic, there are hardly any available continuous records of the complete last interglacial cycle that would convincingly show the change from a cold glacial environment across a rather warm interglacial period and into a progressively cooling phase, neither from land, e.g., Greenland ice cores, circum-Arctic vegetational and shallow-marine coastal records, nor from the Arctic Ocean proper. In spite of this obvious lack of good data and, thus, stratigraphic control, there have been numerous reconstructions, based on temperature estimates and/or numerical modelling, to show that the Arctic region was generally much warmer in MIS 5e than in the Holocene (Anderson et al. 2006), which resulted in a large-scale areal reduction of both Greenland ice (e.g., Cuffey \& Marshall 2000; Overpeck et al. 2005) and Arctic Ocean sea-ice cover (e.g., Otto-Bliesner et al. 2006). Moreover, outside the Arctic itself in the Nordic seas, deep-sea records with good stratigraphic control of the last interglacial period have been interpreted in different ways with respect to the spatial temperature gradients, water mass distribution and climate variability (e.g., Cortijo et al. 1994; Fronval et al. 1998; Bauch et al. 1999).

To shed more light on the topic, the aim of our study was to critically evaluate and interpret some crucial marine palaeo data from the present and the last interglacial period of the eastern Nordic seas (Norwegian Sea). From the palaeoceanographic and palaeoclimatic perspective alike, this area is important for monitoring the main flux of interglacial surface oceanic heat on its northbound flow to the High Arctic.

\section{Material and methods}

\section{Hydrography and core sites}

The modern hydrography of the Norwegian, Greenland and Iceland seas (Nordic seas) is determined by a meridional flow pattern of surface waters (Fig. 1). Relatively warm and saline Atlantic water enters the south-eastern Nordic seas as the Norwegian Atlantic Current (NAC). The Coriolis effect forces a large portion of this Atlanticderived warm water northwards along the Norwegian continental margin, entering the Arctic Ocean through Fram Strait and across the Barents Sea. Today, the NAC does not touch the Norwegian coast directly, as this area is screened by the Norwegian Coastal Current (NCC), a fresher water mass formed from North Sea and Baltic Sea water masses, as well as from coastal run-off. In the opposite direction to the NAC, rather cold and lower salinity waters leave the Arctic Ocean through Fram Strait and flow south as the East Greenland Current (EGC) along the Greenland continental margin. In
Table 1. Geographical position and water depth of cores from the Norwegian Sea.

\begin{tabular}{llll}
\hline & \multicolumn{2}{l}{ Geographical position } & \\
\cline { 2 - 3 } Core Norw. Sea & Latitude & Longitude & Water depth (m) \\
\hline HM52-43 & $64^{\circ} 31^{\prime} \mathrm{N}$ & $0^{\circ} 43^{\prime} \mathrm{E}$ & 2781 \\
M23055 & $68^{\circ} 25^{\prime} \mathrm{N}$ & $4^{\circ} 1^{\prime} \mathrm{E}$ & 2311 \\
M23071 & $67^{\circ} 05^{\prime} \mathrm{N}$ & $2^{\circ} 55^{\prime} \mathrm{E}$ & 1308 \\
M23323 & $67^{\circ} 46^{\prime} \mathrm{N}$ & $5^{\circ} 55^{\prime} \mathrm{E}$ & 1286 \\
MD95-2009 & $62^{\circ} 44^{\prime} \mathrm{N}$ & $3^{\circ} 59^{\prime} \mathrm{W}$ & 1027 \\
MD95-2010 & $66^{\circ} 41^{\prime} \mathrm{N}$ & $4^{\circ} 34^{\prime} \mathrm{E}$ & 1226 \\
MD95-2011 & $66^{\circ} 58^{\prime} \mathrm{N}$ & $7^{\circ} 38^{\prime} \mathrm{E}$ & 1048 \\
ODP644 & $66^{\circ} 40^{\prime} \mathrm{N}$ & $4^{\circ} 34^{\prime} \mathrm{E}$ & 1227 \\
PS1243 & $69^{\circ} 23^{\prime} \mathrm{N}$ & $6^{\circ} 32^{\prime} \mathrm{W}$ & 2710 \\
\hline
\end{tabular}

response to the seafloor topography, parts of the NAC and EGC become deflected towards the central Nordic seas, feeding a new water mass (Arctic waters), with two dominant gyres in the Iceland Sea and in the Greenland Sea. These Arctic waters are separated from the main flow of Atlantic-derived waters by a distinct water mass boundary: the Arctic front (Fig. 1, Table 1).

The core sites selected for this study cover most of the crucial areas of the Norwegian Sea. Thus, they should be well suited to recording any major changes or variations of the meridional circulation. This applies particularly to the periods of peak warmth in the last interglacial period and Holocene times, when global ice volumes were at a minimum, when low global ice volumes brought about similar environmental constraints for these two interglacials.

\section{Stratigraphy and stable isotope analyses}

For comparison with the Holocene, we have selected the published records of cores PS1243 (Bauch et al. 2001), HM52-43 (Veum et al. 1992; Fronval \& Jansen 1997) and MD95-2011 (Riesebrobakken et al. 2003). These cores have well-established last glacial to Holocene chronologies based on radiocarbon dates. However, to better take into account the recent developments in converting radiocarbon years into calendar years, we recalculated the dates of cores PS1243 and HM52-43 by using the method of Fairbanks et al. (2005) and applying a reservoir correction of 400 years. The age chronology of MD95-2011 was taken as that already published.

In Kastencores M23055 and M23071, intervals of the last interglacial period were originally identified by Vogelsang (1990) on the basis of stable carbon and oxygen isotopes measured on the polar planktic foraminifer Neogloboquadrina pachyderma (s). Accordingly, core M23055 reaches back to MIS 7, whereas M23071 penetrates into the deglacial section of MIS 6. For the purpose 


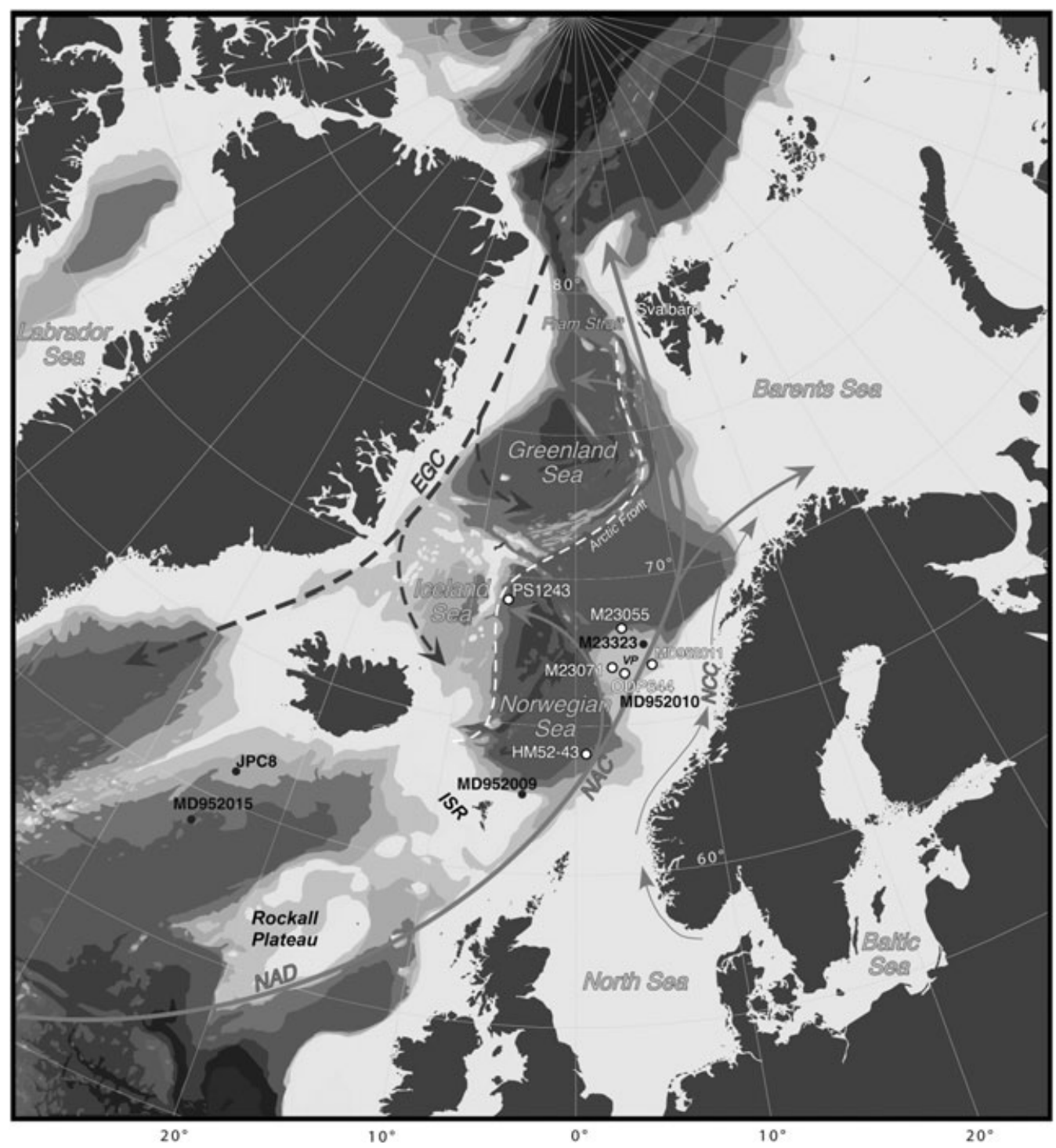

Fig. 1. Map of the subpolar and polar North Atlantic region showing a schematic overview of the meridional surface ocean circulation. The positions of sediment cores studied (large white labels) and discussed in this work (black labels) are indicated. MD95-2010 and ODP644 share the same position. Abbreviations: EGC, East Greenland Current; ISR, Iceland-Scotland Ridge; NAC, Norwegian Atlantic Current; NAD, North Atlantic Drift; NCC, Norwegian Coastal Current; VP, Vøring Plateau.

of this study, we have resampled both cores. M23055 was sampled more or less at the same depth levels as performed previously by Vogelsang (1990). Core M23071, which showed a more promising, i.e., better temporal, resolution than M23055, was sampled more or less continuously every $1 \mathrm{~cm}$. In addition, the core catcher of this Kastencore was also sampled, as it was expected to extend the original record into the earliest deglaciation.

As noted previously, cores from near the Norwegian continental margin usually show extremely high sedimentation rates during the glacial-interglacial transition from MIS 6 to MIS 5e (Bauch et al. 1996). This makes it somewhat difficult to assign the few existing age tiepoints given by the conventional SPECMAP timescale (Martinson et al. 1987). In order to circumvent the problem to some extent, a simple but straightforward age model was reconstructed for core M23071, which appeared to have the highest temporal resolution (i.e., sedimentation rate) of the peak last interglacial section. By using a core from further west (site PS1243) with more even sedimentation rates throughout the MIS 6-MIS 5d interval (Bauch \& Erlenkeuser 2003; unpubl. data), and by assigning the SPECMAP events 6.2, 6.0, 5.53, 5.51 and 5.4 (Martinson et al. 1987), an age scale 
was established via interpolation between these reference depths. The final age model for core M23071 was essentially derived by cross-correlating between the planktic stable isotope curves of the two cores. We do realize at this point that controversial opinions exist as to the validity of the SPECMAP timescale for the onset of the penultimate deglaciation (e.g., Winograd et al. 1992). However, following the concept of SPECMAP (e.g., Imbrie et al. 1992), we assume that northern insolation peaked during the penultimate deglaciation after the glacial maximum of MIS 6, with a similar timelag as it did during the transition from MIS 2 into the Holocene.

Stable isotope ratios were analysed at the Leibniz Laboratory for Radiometric Dating and Stable Isotope Research, Kiel University, using a Finnigan MAT 251 mass spectrometer with the Kiel carbo device (Kiel I, prototype). The analytical accuracy is $\pm 0.07 \%$ o for $\delta^{18} \mathrm{O}$ and $\pm 0.04 \%$ for $\delta^{13} \mathrm{C}$. All results were calibrated to Pee Dee Belemnite (PDB). For the measurements, about 30 specimens (average test size $200 \mu \mathrm{m}$ ) of the planktic foraminifer $N$. pachyderma (s) were used per sample. Oxygen isotopes were also analysed on the epibenthic foraminifer Cibicidoides wuellerstorfi using multiple specimens (ca. 8-10, with an average test size of ca. $400 \mu \mathrm{m})$. In a few samples from the deglacial section, where this species is rarely found, measurements were also performed on a smaller number of tests. The data from core M23055 and M23071 will be compared with published data from ODP644 (e.g., Fronval \& Jansen 1996, 1997), and are then further discussed with more recently interpreted data compiled by the same working group (e.g., Riesebrobakken et al. 2006; Riesebrobakken et al. 2007).

Sediment samples from our cores were usually taken either as 1 -cm-thick slices, or with cut-off syringes $(1 \mathrm{~cm}$ in diameter). All samples were freeze-dried and then routinely washed over a $63-\mu \mathrm{m}$ mesh. Depending on the core, ice-rafted debris (IRD) grains were counted in the size fractions $>150 \mu \mathrm{m}$ or $>250 \mu \mathrm{m}$. IRD is usually expressed as grains per gram of the dry bulk sample. For better comparability between some records, we also expressed IRD records as percentages (of the total of planktic foraminifers and IRD grains in the sample).

\section{Foraminiferal assemblages and modern distribution}

It has been shown by a number of detailed test-size measurements, as well as by discrete size-fraction analyses, that calculating census data of the foraminiferal assemblage in the Nordic seas using different lower mesh size limits (e.g., >125 $\mu \mathrm{m}$ vs. $>150 \mu \mathrm{m}$ ) may lead to quite different results and interpretations (Bauch 1992, 1994; Kandiano \& Bauch 2002). This is particularly true for the species Turborotalita quinqueloba, which could be regarded the "coldest" representative of the entire subpolar fauna. This species is found in last glacial sediments in test sizes below $125 \mu \mathrm{m}$ (Bauch 1994; Hebbeln et al. 1994). Besides inhabiting the Norwegian Sea, T. quinqueloba is also widespread in the Arctic waters of the Nordic seas (e.g., Bé \& Tolderlund 1971; Carstens 1991; Carstens et al. 1997; Schröder-Ritzrau et al. 2001), along with high proportions of the polar species $N$. pachyderma (s). In a study of sediment surface samples from the Norwegian Sea, T. quinqueloba showed an enhanced abundance near the Arctic front (Johannessen et al. 1994) and, accordingly, has often been referred to as an indicator of past positions of the Arctic front (e.g., Fronval et al. 1998). Based solely on the modern analogue in surface samples, this conclusion oversimplifies the actual situation, as T. quinqueloba occurs widely across the Nordic seas, as it did during the early Holocene (e.g., Bauch et al. 1999; Simstich 1999; Sarnthein et al. 2003).

From the biogeographical point of view, the rightcoiled variety of $N$. pachyderma, N. pachyderma (d), could be regarded in the Nordic seas as the "warm" counterpart of the left-coiled polar species $N$. pachyderma (s). In surface sediments, $N$. pachyderma (d) is the most dominant subpolar species in the eastern and south-eastern marginal areas of the Norwegian Sea (Pflaumann et al. 1996; Bauch \& Kandiano 2007). Here, surface waters are warmest (Arctic Climatology Project 1998) but are also influenced by the waters of the NCC (Fig. 1). A more typical representative of the Atlantic-derived waters in the Norwegian Sea appears to be Globigerina bulloides. In surface sediments of the southern Norwegian Sea it can comprise up to $5 \%$ of the entire assemblage $>150 \mu \mathrm{m}$ (Pflaumann 1988).

Within the data set of surface samples, which is based on the $>150-\mu \mathrm{m}$ size fraction, and forms the backbone for estimating past temperatures (Pflaumann et al. 1996), other subpolar species, such as those belonging to the genus Globigerinita, are clearly under-represented because of their smaller sizes. As a result of the collection criteria used in the past, in this study we will rely on faunal data produced from two different size fractions $(>125 \mu \mathrm{m}$ and $>150 \mu \mathrm{m})$. However, this will not affect our main conclusions that are based on cores from the relatively warm eastern Norwegian Sea. In this area, we found that the relative abundance of subpolar species in the surface sample (from the undisturbed trigger boxcorer) of our key site (M23071) differs only marginally between $>125-\mu \mathrm{m}$ and $>150-\mu \mathrm{m}$ mesh sizes, i.e., $57 \%$ vs. $55 \%$, respectively, for the total subpolar fauna, or $24 \%$ and $18 \%$, respectively, for the smaller-sized T. quinqueloba. 


\section{Results}

\section{Holocene records}

Both core sites HM52-43 and PS1243 show a rather harmonic development over the past $20 \mathrm{Ky}$, in that the transition from the Last Glacial Maximum (LGM) into the Holocene was accompanied by the surface ocean changes so typical for the deglacial processes of this region (Fig. 2).
It was only after the Younger Dryas cold event had terminated (ca. $11.5 \mathrm{Kya}$ ) that a drastic change towards interglacial conditions, with strongly decreasing IRD input from melting icebergs and, hence, increasing salinities resulting from the reduced influence of meltwater, is noted. Concomitant with the reduction in meltwater, steeply increasing numbers of subpolar foraminifers (as shown by the reduced polar $N$. pachyderma [s] population; Fig. 2) bear witness to the existence of Atlantic-type
Fig. 2. Proxy record from the Norwegian Sea showing the evolution of surface water masses, as indicated by the proportion of the polar planktic foraminifer Neogloboquadrina pachyderma (s), its oxygen isotope composition and the relative quantity of iceberg-rafted debris (IRD). The records are shown alongside the northern summer insolation $65^{\circ} \mathrm{N}\left(\mathrm{W} \mathrm{m}^{-2}\right.$; Berger 1978), when Arctic-sub-Arctic regions usually show the least seasonal sea-ice cover (from mid-July through to August).
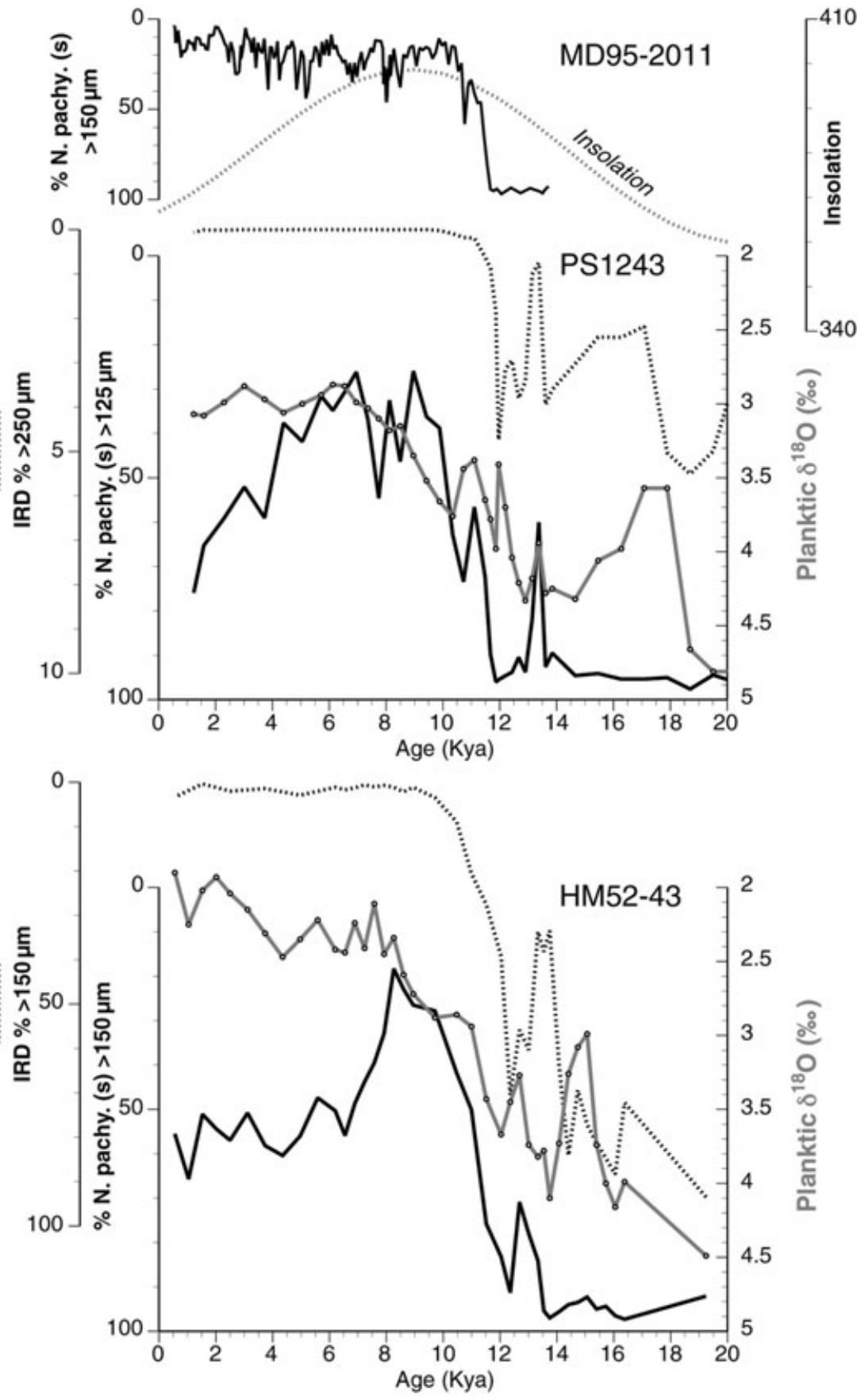


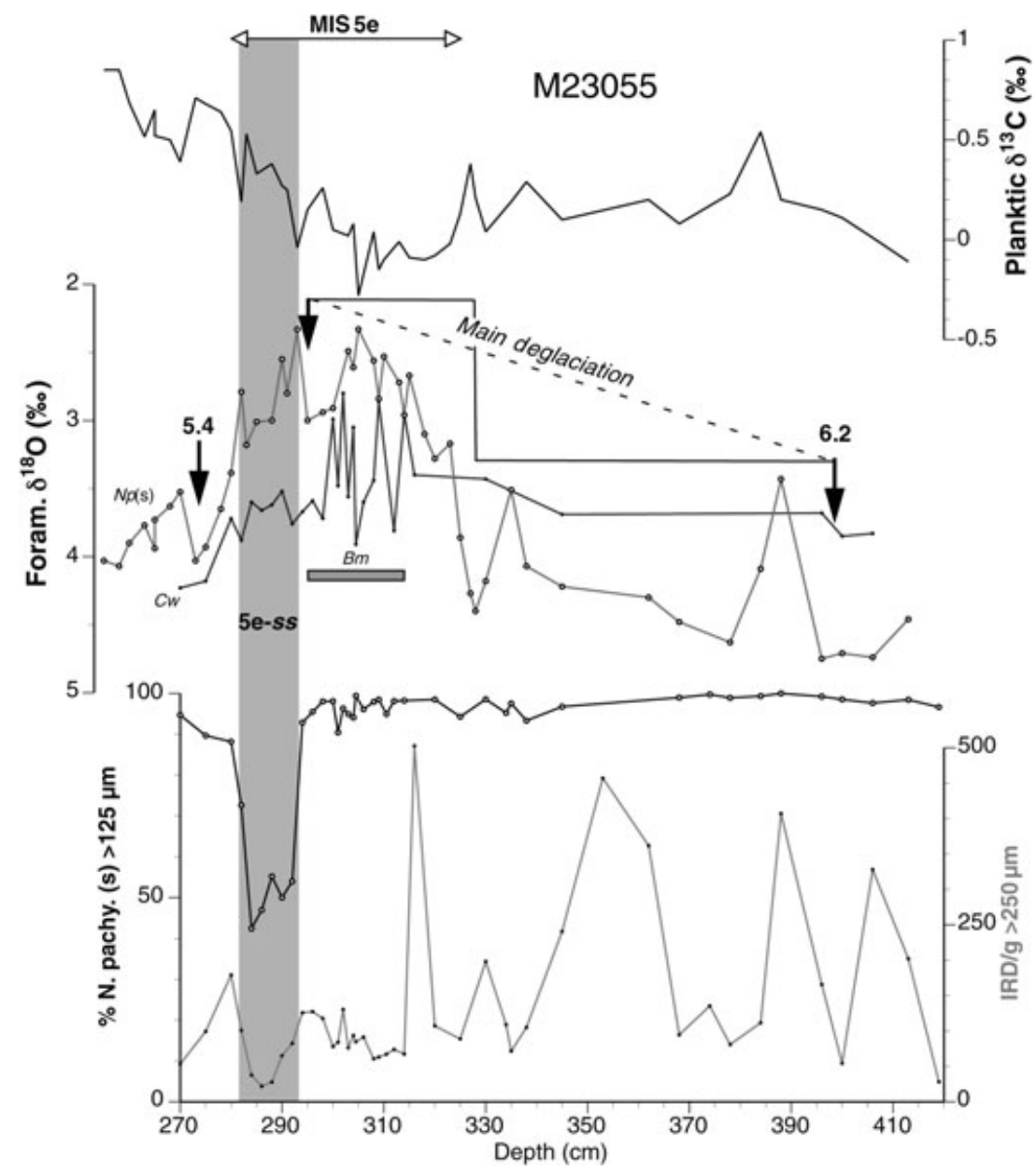

Fig. 3. Various proxy records across MIS 5e from the northern slope of the Vøring Plateau (isotope events 6.2 and 5.4 frame the complete last interglacial cycle). The vertical grey-shaded area represents peak last interglacial conditions sensu stricto (5e-ss), as defined by low levels of ice-rafted debris (IRD) and, simultaneously, low proportions of the polar planktic foraminifer Neogloboquadrina pachyderma (s). The horizontal grey bar marks the occurrence of Beella megastoma $(B m)$ in the core. Abbreviations: $C W$, benthic foraminifer Cibicidoides wuellerstorf; Np(s), Neogloboquadrina pachyderma (s). water mass inflow into the Norwegian Sea, with the "warmest conditions" occurring roughly between 10 and 6.5 Kya, and during a phase of high summer insolation. After this time, surface conditions at the two sites never regained the peak level seen in the early Holocene. This became particularly apparent near the Arctic front (core PS1243), where a steady increase towards polar conditions since mid-Holocene times can be observed.

By comparison, and somewhat contradictory to the records upstream and further west, core MD95-2011 does not show a clear early Holocene peak warming within the foraminiferal assemblage. Although the faunal record also reveals a low polar abundance during this time, the population of $N$. pachyderma (s) remains below $20 \%$ on average throughout the last $10.5 \mathrm{Ky}$. The overall decreasing trend of this species during the last $6 \mathrm{Ky}$ is especially at odds with the other temperature reconstructions on the basis of diatoms and alkenones from this core (Calvo et al. 2002; C. Andersen et al. 2004). All these data do show a clear early to middle Holocene climatic optimum. In fact, in core M23323, a site which is located just slightly to the north-west of MD95-2011 (Fig. 1), ca. 80-90\% of subpolar foraminifers occur within the $>125-\mu \mathrm{m}$ size fraction between 10.5 and 8.5 Kya (Simstich 1999; Bauch et al. 2003), thus also verifying the existence of the early Holocene warm peak for this region on the basis of the planktic foraminiferal assemblage.

\section{The last interglacial period}

Records of the last interglacial period from the northern slope of the Vøring Plateau (Fig. 3) show some very characteristic features of the palaeoceanographic development from the preceding glaciation MIS 6 (Saalian), across the main deglaciation, MIS 5e and into the early phase of the last glaciation. The final phase of MIS 6 (event 6.2) has planktic $\delta^{18} \mathrm{O}$ values similar to the LGM. The deglaciation commenced at ca. $390 \mathrm{~cm}$, with some notable variations, and shows enhanced but variable inputs of IRD and, as a result, also of meltwater. After this inital phase, above a core depth of $325 \mathrm{~cm}$, steeply 
Fig. 4. Various proxy records across MIS $5 \mathrm{e}$ from the Vøring Plateau (isotope events 6.2 and 5.4 frame the complete last interglacial cycle). The vertical grey-shaded area represents peak last interglacial conditions sensu stricto (5e-ss), as defined by low levels of ice-rafted debris (IRD) and low proportions of the polar planktic foraminifer Neog/oboquadrina pachyderma (s). Abbreviations: $\mathrm{CW}$, benthic foraminifer Cibicidoides wuellerstorfi; $N p(s)$, Neogloboquadrina pachyderma (s).

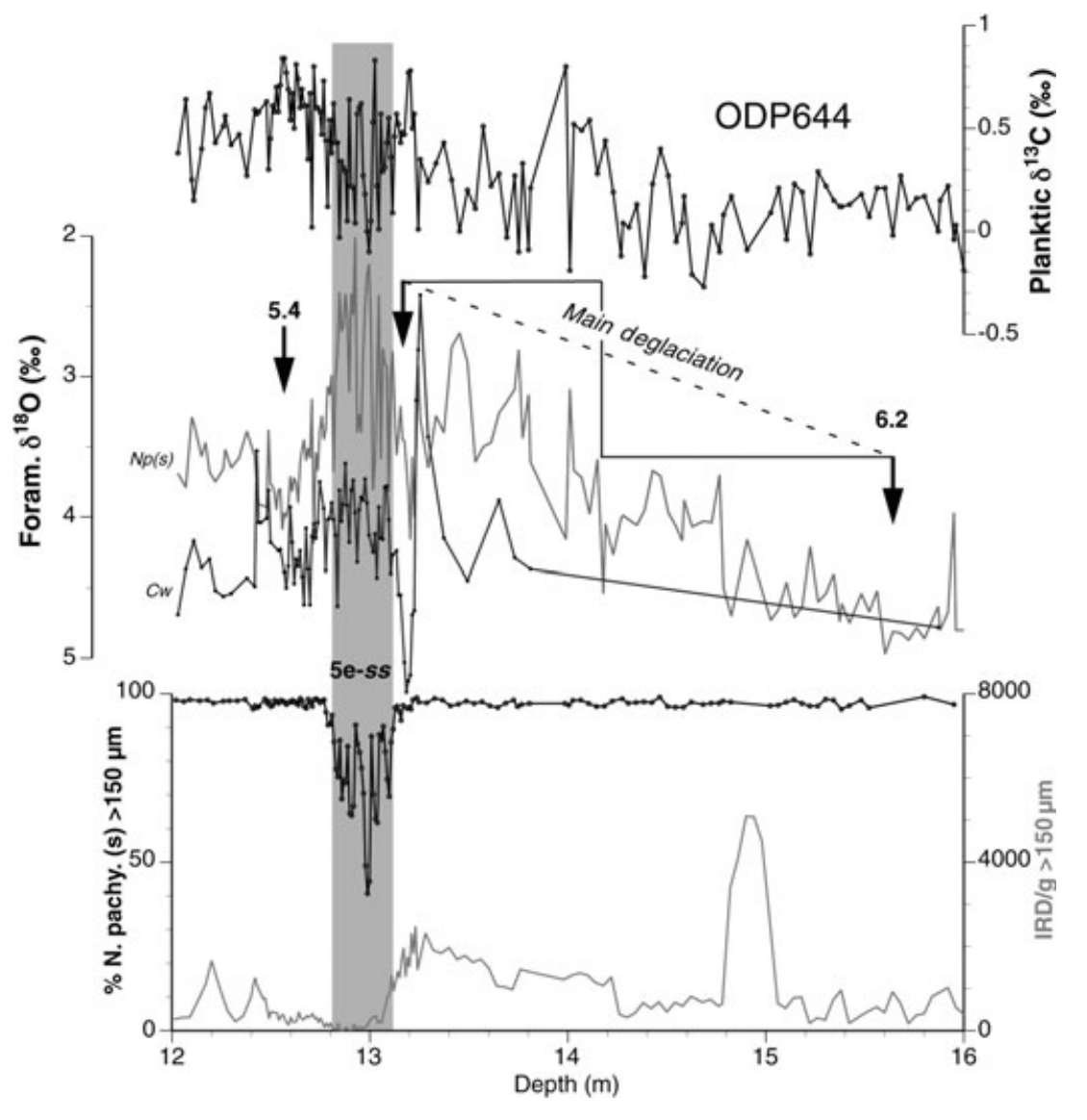

decreasing planktic $\delta^{18} \mathrm{O}$ values provide evidence for a definite environmental change, although a response within the foraminiferal assemblage apparently remains negligible. Benthic $\delta^{18} \mathrm{O}$ values, however, reveal largescale fluctuations (up to $1 \%$ ), especially during this second phase. The main deglaciation terminates in a distinct isotopic trough, reflected in both surface and bottom waters. Above this prominent trough, subpolar forminifers steeply increased in parallel with the reducing input of IRD. The initial phase of a return to glacial conditions is marked by enhanced IRD input, together with rising proportions of $N$. pachyderma (s) and increasing $\delta^{18} \mathrm{O}$ towards isotope event 5.4. As has been stated previously on the basis of some of the records from core M23055 (Bauch et al 1996), the main 5e-ss of the last warm period in the Nordic seas occurred within the upper part of the MIS 5e interval, and the warmest phase occurred towards its very end (see also Haake \& Pflaumann 1989). This now seems corroborated by the benthic $\delta^{18} \mathrm{O}$ record, which reveals relatively stable values of about $3.7 \%$ only during times of high (up to 60\%) subpolar foraminiferal abundance. We stress at this point, however, that because of the thinness of the sediment section, which makes up the peak interglacial part in core M23055 (ca. $15 \mathrm{~cm}$ ), bioturbational effects become strongly enhanced, despite the slice technique applied for sampling.

Overall, proxy records of ODP644 from further south on the Vøring Plateau show reasonable similarity to core M23055 (Fig. 4): a more than 2.5-m thick package of sediment constitutes the main deglacial interval. This deglaciation shows large-scale variations in $\delta^{18} \mathrm{O}$, and both benthic and planktic isotopic records terminate towards the uppermost end of the deglaciation in a distinct isotopic trough. Again, this prominent trough occurred just prior to the onset of interglacial conditions, which is marked by steeply increasing subpolar foraminiferal abundance, and concomitant cessation of IRD deposition. A relatively thin interval (ca. $30 \mathrm{~cm}$ ) comprises the peak interglacial part of MIS 5e. The transition down to isotope event 5.4 is characterized by increasing $\delta^{18} \mathrm{O}$ values and polar surface water conditions.

Apart from the overall similar trends between the proxy records of M23055 and ODP644, there are nevertheless major differences to be noted. For instance, the faunal record of ODP644 shows large changes within 5e-ss. These changes have been repeatedly shown alongside with the disturbed, lower section of the GRIP ice core (Fronval \& Jansen 1996, 1997), despite the fact that the 


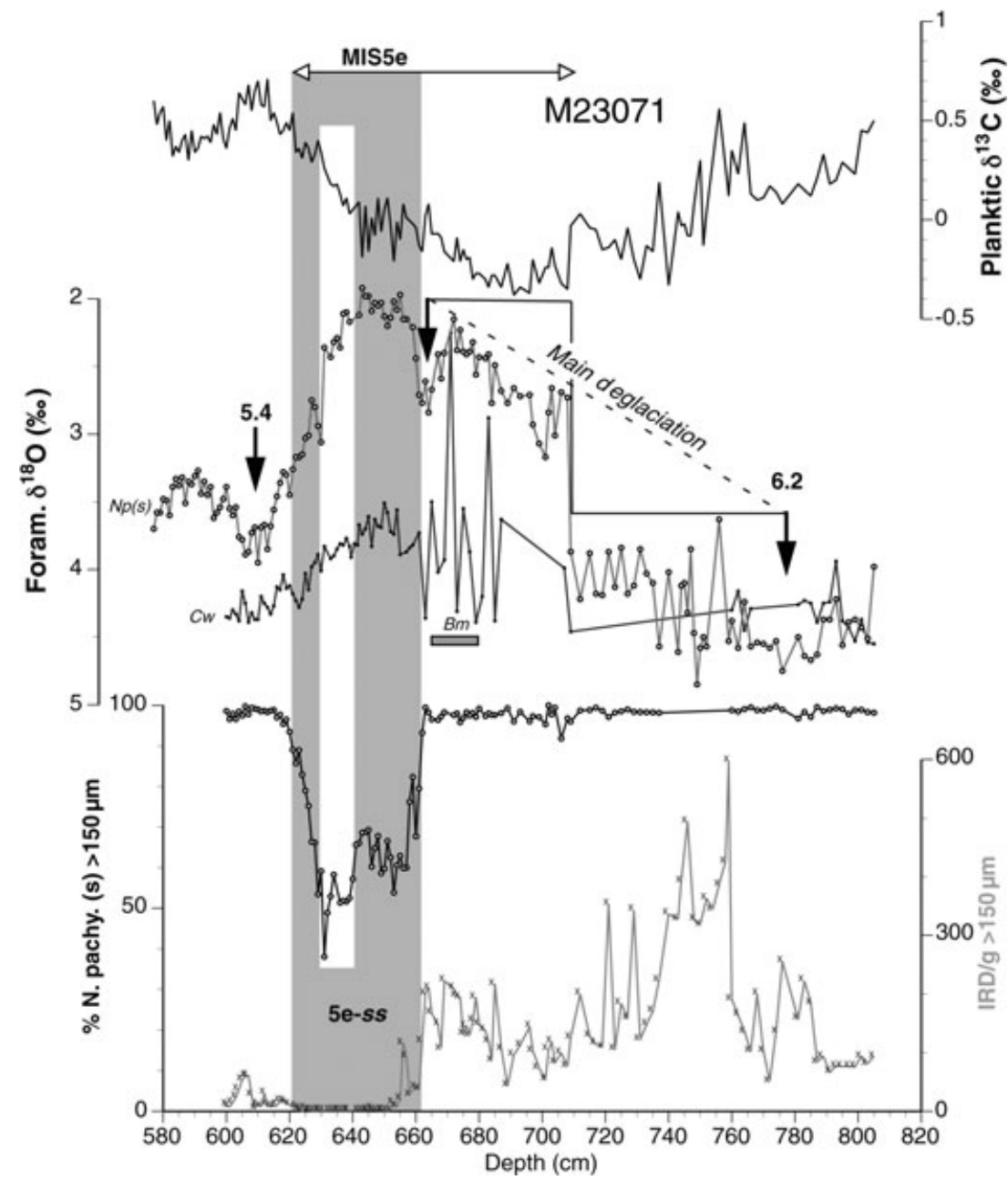

Fig. 5. Various proxy records across MIS $5 \mathrm{e}$ from the Vøring Plateau (isotope events 6.2 and 5.4 frame the complete last interglacial cycle). The vertical grey-shaded area represents peak last interglacial conditions sensu stricto (5e-ss), as defined by low levels of IRD and low proportions of the polar planktic foraminifer Neogloboquadrina pachyderma (s); the white area within highlights the interval with highest surface ocean temperatures. The horizontal grey bar marks the occurrence of Beella megastoma $(\mathrm{Bm})$ in the core. Abbreviations: $\mathrm{Bm}$, Beella megastoma; $\mathrm{CW}$, benthic foraminifer Cibicidoides wuellerstorfi; Np(s), Neogloboquadrina pachyderma (s). originally published interpretation of the GRIP core (Dansgaard et al. 1993) was found to be erroneous only shortly after publication (Grootes et al. 1993).

Another, noteworthy difference between the two marine cores is the actual position of the warmest part within 5e-ss. This is clearly not at the end of 5e-ss in core ODP644. Although subpolar abundances rise up to $60 \%$ during its short peak, the remaining section is dominated by $N$. pachyderma (s) constituting between 60 and $80 \%$ of the foraminiferal assemblage.

In order to further evaluate the differences between cores M23055 and ODP644, in our study we have included core M23071 from a similar water depth as ODP644, but located just slightly further west (ca. $46 \mathrm{~nm}$ ). Again, the main deglaciation in this core (Fig. 5) shows all the characteristic features already described from the other two sites. In particular the IRD data reveal a good similarity in all cores, in that the rather dominant depositional event occurred during step I of the deglaciation period. However, a second, considerably less prominent, IRD increase is found within the upper part of step II. Notwithstanding the many more minor IRD events, for instance, near the end of the deglaciation (at ca. $657 \mathrm{~cm}$ in M23071), this two-stepped nature, with virtually no response among the dominant planktic foraminiferal species, appears to be the typical feature of iceberg discharge events at the Vøring Plateau during deglaciation.

The 5e-ss section in core M23071 commenced with a steep increase in subpolar abundance (up to $45 \%$ ). After a phase of some minor variability but with a decreasing trend, which terminated in a trough (centred at $643 \mathrm{~cm}$ ), the main warm interval of $5 \mathrm{e}$-ss occurred between 640 and $628 \mathrm{~cm}$, when subpolar abundance reached more than $60 \%$ within a very short interval. It is this second, warmer interval that is accompanied by, on average, heavier $\delta^{18} \mathrm{O}$ values in both benthic and planktic foraminifers. This may imply that the $\delta^{18} \mathrm{O}$ values during the first warm interval contain a freshwater component of measurable quantity. 
The transition down to isotope event 5.4 is marked by a steep increase towards polar conditions. Interestingly, whereas the polar faunal record does not reveal any observable variability, there are two notable events in the $\delta^{18} \mathrm{O}$ records. The first one is found mainly in the planktic record at a core depth of $627 \mathrm{~cm}$, just prior to the recurrence of IRD. The second event is very easily recognizable in both $\delta^{18} \mathrm{O}$ records, and coincided with the deposition of increased quantities of IRD. In fact, two more benthic $\delta^{18} \mathrm{O}$ spikes are seen further up in core M23071 (around isotope event 5.4), and each of them seems to have its counterpart in the IRD record.

The good comparability between all proxy records from cores M23071 and M23055 discussed so far is corroborated by the planktic $\delta^{13} \mathrm{C}$ record of $N$. pachyderma (s). In these two cores, both carbon records do show a very similar evolution during early deglaciation, with a prominent interval during step II marked by lowest values. This high isotopic similarity is retained across the remaining 5e-ss section and into the glacial inception, in both absolute values and variability. By comparison, all isotopic records of ODP644 show large-scale amplitude changes, casting doubt on their quality as a reliable palaeoenvironmental recorder. In a similar way, this may apply to the faunal data during $5 \mathrm{e}-s s$, which are so similar between cores M23055 and M23071 in trend and absolute values, despite the very different sedimentation rates, but which differ significantly from the data from core ODP644.

\section{Discussion}

\section{5e-ss}

According to our age model, the part of MIS 5e in core M23071 that would compare directly with the interglacial conditions of the Holocene since 11.5 Kya lasted for $\leq 9 \mathrm{Ky}$, from 124.5 to $115.5 \mathrm{Kya}$ (Fig. 6). This is clearly confirmed by the populations of all dominant subpolar species which started to increase in numbers at the same time, and is contemporaneous with the steep decrease in planktic $\delta^{18} \mathrm{O}$, as well as high insolation. It is rather noteworthy that towards the end of 5e-ss, at 116.5 Kya, the ultimate turning point in the subpolar species T. quinqueloba and $G$. bulloides was again associated with a similar steep change in planktic $\delta^{18} \mathrm{O}$, but with the opposite effect because of the cooling surface conditions. Although most subpolar foraminifers seem to have reached their abundance peaks between 118 and 116.5 Kya, N. pachyderma (d) shows its dominance clearly before that. At face value one could be tempted to assume that the late high abundance of T. quinqueloba in particular reflects the eastward shift of cooler Arctic Waters (i.e., including the Arctic front sensu Johannessen et al. 1994) during times of early glacial inception. The peak in T. quinqueloba, however, occurred simultaneously with the peak in G. bulloides, a species that can clearly be regarded as a solid indicator for North Atlantic surface waters flowing into the Norwegian Sea (Pflaumann 1988; Bauch \& Kandiano 2007). By contrast, surface samples give ample evidence of a welldefined biogeographical and ecological preference of $N$. pachyderma (d) for the marginal areas, stretching from the North Sea, north along the Norwegian coast, where coastal waters of the NCC are the dominating oceanographic factor (see Bauch \& Kandiano 2007). Such a preference does not discount $N$. pachyderma (d) from also being a representative of a typical interglacial water mass circulation in the Norwegian Sea in general. But it would rule out this species from being a direct indicator of the north-directed meridional transfer of ocean heat from the North Atlantic, in particular, as is often inferred in other studies (e.g., Fronval et al. 1998; Riesebrobakken et al. 2007).

In two recent investigations, Riesebrobakken et al. (2006) and Riesebrobakken et al. (2007) show various proxy records of MD95-2010 from the Vøring Plateau; this core was taken in 1995, apparently to restudy ODP644 as both sites share exactly the same position (Fig. 1). The published planktic foraminiferal census data from this new core reveal that the main decrease in the polar species $N$. pachyderma (s) clearly occurred during the early part of 5e-ss. What comes as a surprise is that none of the large-scale faunal and isotopic variabilities originally compiled and interpreted from core ODP644, data often cited and used by others (e.g., Müller \& Kukla 2004), could even roughly be reproduced from MD952010. Furthermore, although the original and new data from the two cores share the same site, and were compiled within the same working group, all previous studies and interpretations of ODP644 were not referred to in the subsequent, more recent studies of core MD95-2010.

That core MD95-2010 shows the warmest conditions during early 5e-ss strongly conflicts with our data from cores M23071 and M23055. In fact, it also opposes data and interpretations made from a site further upstream, i.e., core MD95-2009 at the Iceland-Scotland Ridge (Fig. 1). On the basis of crucial planktic foraminiferal data from this core, there is unequivocal evidence of the late, peak warm interval (Rasmussen et al. 1999; Rasmussen et al. 2003), in absolute accordance with our data.

In the latest interpretation, the faunal data of core MD95-2010 were compared with records from the south-west of Svalbard, where a clear late warm peak is recognized in MIS 5e (Riesebrobakken et al. 2007). These authors, who also employ a modelling approach, claim that this phase difference between the early warm peak at the Vøring Plateau and the later warm peak off Svalbard 


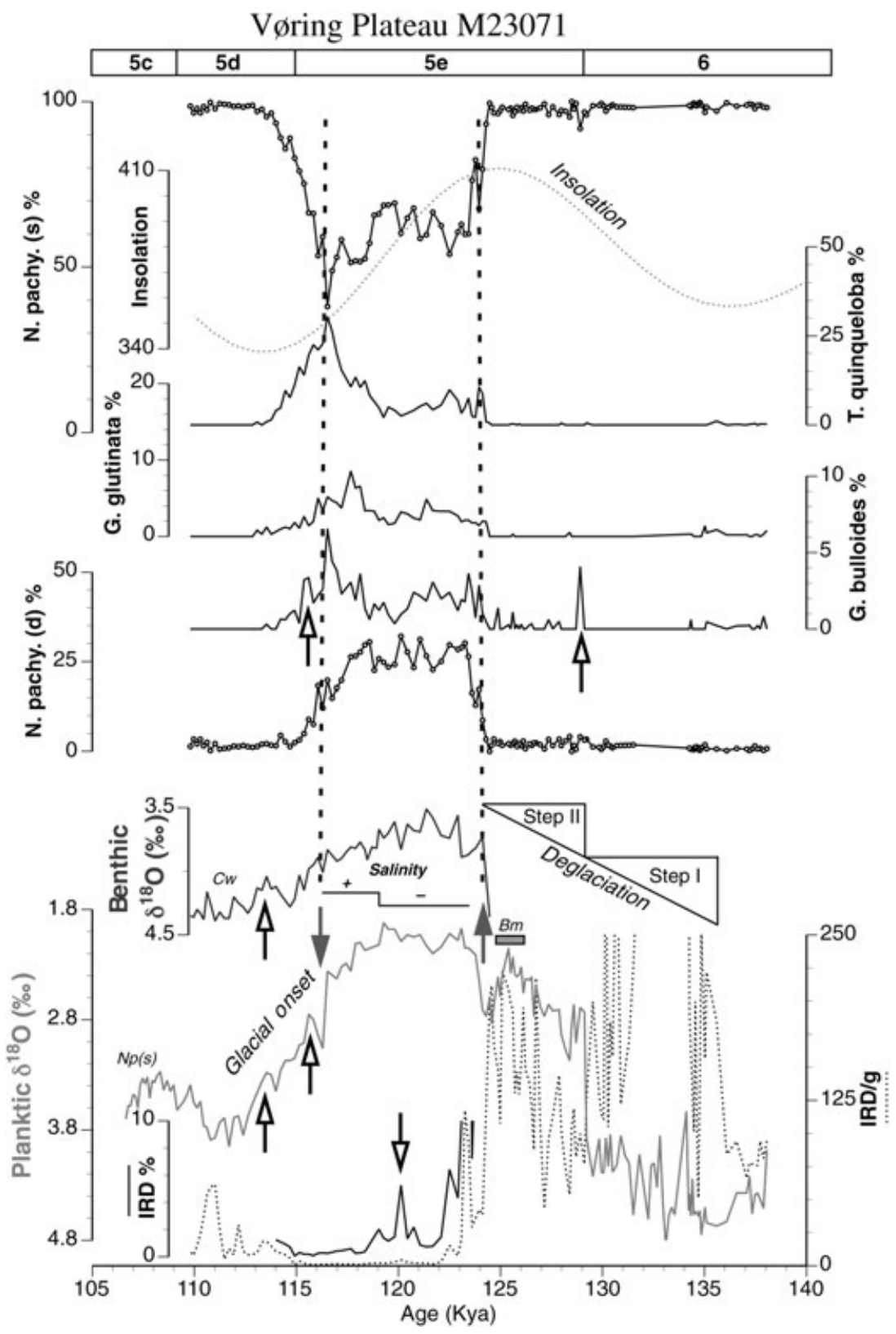

Fig. 6. Comparison of planktic foraminiferal asemblage data, planktic and benthic oxygen isotopes ( $\mathrm{Np}[\mathrm{s}]$ and $\mathrm{CW}$ ) and sedimentological records of key core $M 23071$, shown alongside with northern summer insolation $\left(\mathrm{W} \mathrm{m}^{-2}\right.$, as in Fig. 2) for the period 140-105 Kya. Also indicated are the stepwise deglaciation and the glacial inception. Dashed vertical lines together with up- and down-pointing solid arrows frame the peak interglacial time sensu stricto (5e-ss). The highest ocean surface temperatures occurred during times when highest salinites are inferred and surface water advection from the Atlantic to the Vøring Plateau was most intense. Up- and down-pointing open arrows denote some further events, as discussed in the text. was a main forcing (i.e., controlling moisture supply, atmospheric circulation, etc.), which triggered enhanced glacier growth in the northern Barents Sea region and its archipelagos during early glacial inception.

Indeed, it has often been suggested, in accordance with the orbital theory, that the steeply decreasing insolation values at high northern latitudes during MIS 5e was the main trigger that enforced early glacial inception in this region (e.g., Imbrie et al. 1992). An analogy of this is certainly found over large areas of the Nordic seas after the early to middle Holocene warm peak, when surface ocean cooling occurred contemporaneously with both lowered insolation and mountainous glacier growth in Norway (Koç et al. 1993; Bauch et al. 1996; Nesje \& Kvamme 1991; Hald et al. 2004; see also Fig. 2). However, the occurrence of the warmest peak during late $5 \mathrm{e}-s s$ is somewhat contradictory with this Holocene analogy. It has therefore been suggested that the deglaciation of the much larger Saalian (MIS 6) vs. Weichselian (MIS 2) ice sheet led to quite contrasting environmental boundary conditions (Bauch \& Kandiano 2007). These were enforced by different glacial-deglacial histories, and resulted from the combined effects of meltwater release to the Nordic seas and inflow of Atlantic water, as well as 
the regional sea level changes caused by global deglaciation and glacial rebound of Fennoscandia. Therefore, a significant time lag in postdeglacial climate evolution developed between the higher and middle latitudes of the North Atlantic sector. In accordance with peak northern insolation, the warmest surface conditions clearly occurred on the southern Rockall Plateau during the initial phase of MIS 5e, with a second, slightly cooler, warm peak discernible towards the terminal phase of MIS 5e (Bauch \& Kandiano 2007). Further north in the Iceland Basin, estimates of the sea surface temperature from core JPC8 (Fig. 1) indicate instead a slightly warmer late MIS 5e (Oppo et al. 1997; Bauch et al. 2000). This late MIS 5e warming in this particular region now seems to be confirmed by a palynological study of core MD952015 (Fig. 1), revealing an unusually high abundance of the warm, Atlantic-type dinocyst Spiniferites mirabilis (Eynaud et al. 2004).

A recent palynological investigation of core M23071 has also revealed the occurrence of $S$. mirabilis on the Vøring Plateau, in synchrony with the occurrence of peaks in G. bulloides and T. quinqueloba (Van Nieuwenhove et al. 2008). This new finding strongly suggests that fully marine, Atlantic-type conditions developed at site M23071 only after $118 \mathrm{Kya}$, and that the lower planktic $\delta^{18} \mathrm{O}$ values (and possibly benthic $\delta^{18} \mathrm{O}$ values, too) found previously mainly reflect an influence of water masses with lower salinities. An influence of freshwater from melted icebergs before 119 Kya cannot be ruled out entirely, as we find a slight, but distinct, increase in IRD at 120 Kya followed by a subsequent cooling, recorded by all subpolar foraminfers (Fig. 6). Because of the low resolution, we do not intend to overinterpret the data from core M23055. But, based on the overall stratigraphic context, it seems as if the low planktic $\delta^{18} \mathrm{O}$ spikes found between core depths of 295 and $288 \mathrm{~cm}$ (Fig. 3) correlate in time with the interval 124-119 Kya in core M23071.

Thus, in analogy to the modern biogeographical distribution of $N$. pachyderma (d), it is suggested that the high abundance of this species in M23071during the first phase of 5e-ss was also the result of a water mass with lower salinity, i.e., a water mass with properties similar to the modern NCC. During the intial phase of $5 \mathrm{e}-\mathrm{ss}$, this water mass was relatively thick, as it reached across the Vøring Plateau down to a water depth of $1300 \mathrm{~m}$, forming conditions there that were less preferred by the other subpolar species. To what extent this water mass was also fed by water from the North Sea/Baltic Sea region remains an open question, but seems rather likely, considering the deglacial and isostatic history of the entire area during the last interglacial period (e.g., Seidenkrantz \& Knudsen 1997; Winn et al. 2000; Funder et al. 2002).
The existence of a water mass with lowered salinity during the earlier stage of 5e-ss must have brought about seasonal differences in surface stratification and temperatures that do not match the Holocene situation. Indeed, this assumption gains support from new reconstructions using dinoflagellate assemblage studies, which show that surface salinity steadily increased across the 5e-ss interval (Van Nieuwenhove \& Bauch 2008 [this issue]). As the same salinity trend was also found across MIS 5e in a core from the southern Labrador Sea (Hillaire-Marcel et al. 2001), it seems as if those northern regions that were in proximity of the formerly heavily glaciated land areas underwent a similar surface water evolution.

\section{Last interglacial climate transitions}

As is evident from the massive deposition of IRD at the Vøring Plateau, in combination with the planktic $\delta^{18} \mathrm{O}$ record, the penultimate deglaciation came in two major steps (Fig. 6). In fact, the early step-event of this transition has a global significance, as it is also easily recognizable in the standard SPECMAP $\delta^{18} \mathrm{O}$ curve (Martinson et al. 1987), as well as in other reconstructions (e.g., Sarnthein \& Tiedemann 1990). More recent studies of the step-like appearance speak of a "pause" in the overall deglacial process (e.g., Gouzy et al. 2004; Riesebrobakken et al. 2006), or even a significant drop in sea level (Siddall et al. 2006). Regardless of the relevance of these new interpretations, in the subpolar north-east Atlantic a major iceberg discharge event was associated with surface cooling during the penultimate deglaciation, and has originally been labelled $\mathrm{Hll}$ in accordance with the younger series of such events (McManus et al. 1994). Intriguingly, at the Vøring Plateau we would infer two such major events on the basis of IRD alone, as have others (Riesebrobakken et al. 2006), and two events have also been described from the southern Rockall Plateau (Didié \& Bauch 2000). However, unlike the record from further south, where these two IRD events were linked to contemporaneous surface cooling (Kandiano et al. 2004), nothing obvious is recognized in the polar faunal record at the Vøring Plateau. Yet, a sample from the early deglaciation in M23071 that yielded an unusually high number of G. bulloides (12 specimens) is noteworthy, although the remainder of the sample was entirely comprised of $N$. pachyderma (s). This sample is found at $129 \mathrm{Kya}$, and it correlates to the steep decrease in planktic $\delta^{18} \mathrm{O}$ (Fig. 6).

Always in association with strong depletions in benthic $\delta^{18} \mathrm{O}$, the penultimate deglaciation of the Nordic seas was marked by the intrusion of the subtropical planktic foraminifer Beella megastoma in the Iceland Sea at the end of 
step I (Bauch 1996; Bauch et al. 2000). Probably as a result of a thick meltwater lid closer to the Norwegian margin, records from further east show that the intrusion occurred either later in time or not at all (Bauch 1996). In core M23071, the record is extremely sparse, as only four samples revealed one specimen each between 126 and 124.5 Kya (Fig. 6). The events recognized in core M23055 cover a roughly similar stratigraphical position as the few specimens in M23071 (Fig. 3). What makes the appearance of $B$. megastoma so significant for interpreting deglacial processes in the Nordic seas is that it testifies to an "Atlantic" water mass component. For this, and for much of the other evidence shown and discussed elsewhere (e.g., Rasmussen et al. 1996; Bauch et al. 2000; Bauch et al. 2001; Jung \& Vogt 2004; Shaffer et al. 2004), the widespread occurrence of highly depleted $\delta^{18} \mathrm{O}$ values in benthic foraminifers cannot be caused by brines ejected during sea-ice formation alone, as has been repeatedly suggested (e.g., Veum et al. 1992; Fronval \& Jansen 1996; Dokken \& Jansen 1999; Riesebrobakken et al. 2006). Unlike other attempts (Bauch \& Bauch 2001), the "brine hypothesis" has so far failed to provide any further evidence or arguments to explain how brines could rapidly fill and replace deep-basin water masses of the Nordic seas, during times when quite contrasting climatic background conditions prevailed (see Bauch \& Erlenkeuser 2003).

Data from the North Atlantic have revealed two cold events, C26 and C25, during the interglacial transition towards isotope event 5.4 (Chapman \& Shackleton 1999; Lehman et al. 2002), and clearly after full interglacial conditions had ceased (Bauch \& Kandiano 2007). Although we did not match our age model from the Vøring Plateau with the records from much further south, it appears evident that the two events recorded in the planktic $\delta^{18} \mathrm{O}$ data of M23071 at 116 and 114 Kya would correlate, respectively, with C26 and C25, and the subsequent brief warmings (Fig. 6). This cooling and warming of the older event is also recognizable in the faunal record of $G$. bulloides. Although a much stronger impact is found on the isotopic proxies in association with IRD during the younger event, there was no response in the subpolar records. Thus, it may be concluded that the brief warming found in G. bulloides near 115.5 Kya may correlate with the warming event recognized in the North Greenland ice core during glacial inception (K.K. Andersen et al. 2004; Bauch \& Kandiano 2007). Still, the overall response in the Nordic seas appears to have been rather weak. This may imply that there was no strong link between atmospheric change over Greenland and variations in the meridional flux of Atlantic surface water into the Norwegian Sea during the early phase of the last glacial cycle.

\section{Holocene versus last interglacial period}

On the basis of a large number of cores from key locations in the Nordic seas, Bauch et al. (1999) attempted to reconstruct the main difference between the last and the present interglacial surface circulation pattern. The pattern that emerged differed from reconstructions by Kellogg (1980) and Fronval et al. (1998), which were rather similar to each other, in showing a weaker influx of Atlantic water into the Norwegian Sea and into the Arctic Ocean when compared with the Holocene. As it was then suggested, the weaker influx resulted in a zonal alignment of the main oceanic fronts (e.g., the Arctic front), a view also favoured because the western Iceland Sea indicated slightly warmer last interglacial conditions than in the Holocene. A relatively warmer south-western Nordic sea, resulting from a weakened EGC responding to a reduced water mass inflow to the Arctic Ocean, may comply with assumptions on a smaller size of the south Greenland ice sheet (Koerner 1989; Cuffey \& Marshall 2000), and the lack of deep-water ventilation in the Labrador Sea (Hillaire-Marcel et al. 2001). It must be stressed at this point, however, that the previous reconstruction from the Nordic seas lacked the high sample resolution of the present study, and did not clearly distinguish between an early and a late $5 \mathrm{e}-s s$ phase (Bauch et al. 1999).

Still, evaluating all the new foraminiferal census data available does not really lead to a very different picture: nowhere in the Norwegian Sea did the proportion of subpolar foraminifers exceed the high values found during the first half of the Holocene at the selected sites at any time during 5e-ss. In fact, taking the Holocene data of Riesebrobakken et al. (2003) from core MD95-2011 as valid for the entire eastern Norwegian Sea, then this statement would apply for most of the Holocene (Fig. 2). But, as has already been indicated, the particular subpolar record in the Holocene of core MD95-2011 is not confirmed anywhere south (HM52-43; Fronval \& Jansen 1997), west (PS1243; Bauch et al. 1996) or in closer vicinity of its position (M23323; Simstich 1999). As a matter of fact, not even the average subpolar trend in MD95-2011 is actually verified by other surface ocean proxy methods conducted on the very same core (Calvo et al. 2002; C. Andersen et al. 2004). And even much further north, reconstructions indicate a very warm early Holocene on the basis of planktic foraminiferal data (Sarnthein et al. 2003; Hald et al. 2004), in strong contrast to the situation in $5 \mathrm{e}$-ss. In this context, a recent re-evaluation of Holocene data from sites stretching from the northern North Sea north along the NorwegianBarents Sea continental margin, towards Svalbard, also reveals very high proportions of $N$. pachyderma (d) in the 
marginal areas during the second half of the Holocene (Hald et al. 2007), thus masking the overregional signal of the warmest period in the early Holocene.

\section{Conclusions}

The last interglacial climate maximum, i.e., the time when Atlantic water inflow was most dominant in the Norwegian Sea, occurred rather late along the meridional pathway of ocean heat transfer towards the Arctic, and during times of already very low insolation forcing. At times when northern summer insolation was higher, i.e., in the early phase of $5 \mathrm{e}$-ss, water masses in the eastern Norwegian seas were affected by lower salinity and some climate instability, which were likely to have resulted from effects connected to the radical environmental change from the glacial to the interglacial regime. Thus, the response to insolation forcing would have been quite different in early 5e-ss if there had been more (quasi) stationary conditions of an already better established equilibrium system, such as probably existed in the earlier Holocene.

Our findings pose large question marks on those modelling attempts for the High Arctic that usually use insolation as the major forcing (e.g., Montoya et al. 1998; Otto-Bliesner et al. 2006; Overpeck et al. 2005). Major doubts also remain for the reconstructions that suffer from a rather "floating" stratigraphic control. For instance, the finds of so-called "warm-loving" and, in shallow water, living molluscs in some coastal outcrops are widely used to generally infer a much warmer last interglacial period than the Holocene (Funder et al. 2002; Anderson et al. 2006). But, because of a poor knowledge of the details of the last interglacial isostatic history of the western and northern North European continental and land margins, such finds lack realistic age control. By analogy with the Holocene isostatic evolution of this region, one could conclude that these "warm" indicators should belong to the earlier part of MIS 5e, i.e., to the late deglaciation and early 5e-ss. By this time, the formerly extensive Saalian ice sheet on the bounded shelf regions all around Fennoscandia was probably gone (e.g., Lambeck et al. 2006), giving way to widespread intrusions of marine waters (Funder et al. 2002). The inflow was aided by the overdeepened shelf areas, a delayed regional isostatic response and a contemporaneous, rapid rise in the global sea level. As indicated by our data from the Vøring Plateau, we assume that during early 5e-ss the eastern Norwegian Sea was largely affected by marine waters, but with a lowered salinity, as they were probably mixed waters from the inundated shelf regions (North-Baltic Sea region). By comparison, the water masses that affected the eastern Norwegian Sea in the early Holocene were more directly connected to the inflow of Atlantic surface water.

Regardless of the precise stratigraphic context of these shallow marine sediments within MIS 5e, and this still remains an open question, our study documents a lower influx of Atlantic waters towards the Arctic in MIS 5e. Moreover, although the last interglacial period is identifiable at the northern Barents Sea margin (Matthiessen \& Knies 2001), and perhaps also north of Greenland (Nørgaard-Pedersen et al. 2007), as yet there exists no primary data basis good enough to justify a large-scale reconstruction of the last interglacial period temperatures, as recently compiled by the CAPE group (Anderson et al. 2006), neither for the terrestrial nor for the marine Arctic realm. We cannot judge the methodological quality of proxy data production, core site selection, coring and sampling made by others. This we have to take for granted. But, in assembling a coherent palaeoceanographic picture of the last interglacial period. But, in assembling a coherent palaeoceanographic picture of the last interglacial period, for the polar north, reconstructions should rely on those records and those sites that, after critical evaluation, appear worthy of confidence as to the overregional climate signals.

\section{Acknowledgements}

The team from the Leibniz Laboratory for Radiometric Dating and Stable Isotope Research, Kiel University, is thanked for their support in isotope analyses. Thanks are expressed to the two anonymous referees for their help to improve the manuscript. The project was funded through grants provided by the German Research Foundation.

\section{References}

Andersen C., Koç, N., Jennings A. \& Andrews J.T. 2004. Nonuniform response of the major surface currents in the Nordic seas to insolation forcing: implications for the Holocene climate variability. Paleoceanography 19, PA2003, doi: 10.1029/2002PA000873.

Andersen K.K., Azuma N., Barnola J.M., Bigler M., Biscaye P., Caillon N., Chappellaz J., Clausen H.B., Dahl-Jensen D., Fischer H., Fluckiger J., Fritzsche D., Fujii Y., Goto-Azuma K., Gronvold K., Gundestrup N.S., Hansson M., Huber C., Hvidberg C.S., Johnsen S.J., Jonsell U., Jouzel J., Kipfstuhl S., Landais A., Leuenberger M., Lorrain R., Masson-Delmotte V., Miller H., Motoyama H., Narita H., Popp T., Rasmussen S.O., Raynaud D., Rothlisberger R., Ruth U., Samyn D., Schwander J., Shoji H., Siggard-Andersen M.L., Steffensen J.P., Stocker T., Sveinbjornsdottir A.E., Svensson A., Takata M., Tison J.L., 
Thorsteinsson T., Watanabe O., Wilhelms F. \& White J.W.C. 2004. High-resolution record of Northern Hemisphere climate extending into the last interglacial period. Nature 431, 147-151.

Anderson P., Bennike O., Bigelow N., Brigham-Grette J., Duvall M., Edwards M., Frechette B., Funder S., Johnsen S., Knies J., Koerner R., Lozhkin A., Marshall S., Matthiessen J., Macdonald G., Miller G., Montoya M., Muhs D., Otto-Bliesner B., Overpeck J., Reeh N., Sejrup H.P., Spielhagen R., Turner C. \& Velichko A. 2006. Last interglacial Arctic warmth confirms polar amplification of climate change. Quaternary Science Reviews 25, 1383-1400.

Arctic Climatology Project 1998. Environmental Working Group joint US-Russian atlas of the Arctic Ocean-summer period. L. Timokhov \& F. Tanis (eds.). Ann Arbor, MI: Environmental Research Institute of Michigan in association with the National Snow and Ice Data Center. CD-rom.

Bauch H.A. 1992. Test size variation of planktic foraminifers as response to climatic changes. Abstracts, 4th International Conference on Paleoceanography. GEOMAR Report 15, 56.

Bauch H.A. 1994. Significance of variability in Turborotalita quinqueloba (Natland) test size and abundance for paleoceanographic interpretations in the

Norwegian-Greenland Sea. Marine Geology 121, 129-141.

Bauch H.A. 1996. Monitoring Termination II at high latitude anomalies in the planktic foraminiferal record. Marine Geology 131, 89-102.

Bauch D. \& Bauch H.A. 2001. Last glacial benthic foraminiferal $\delta^{18} \mathrm{O}$ anomalies in the polar North Atlantic: a modern analogue evaluation. Journal of Geophysical Research-Oceans 106(C5), 9135-9143.

Bauch D., Darling K., Simstich J., Bauch H.A., Erlenkeuser H. \& Kroon D. 2003. Palaeoceanographic implications of genetic variation in living North Atlantic Neogloboquadrina pachyderma. Nature 424, 299-302.

Bauch H.A. \& Erlenkeuser H. 2003. Interpreting glacial-interglacial changes in ice volume and climate from subarctic deep water foraminiferal $\delta^{18} \mathrm{O}$. In A.W. Droxler et al. (eds.): Earth's climate and orbital eccentricity: the marine isotope stage 11 question. Geophysical Monograph Series 137. Pp. 87-102. Washington, D.C.: American Geophysical Union.

Bauch H.A., Erlenkeuser H., Fahl K., Spielhagen R.F., Weinelt M.S., Andruleit H. \& Henrich R. 1999. Evidence for a steeper Eemian than Holocene sea surface temperature gradient between Arctic and sub-Arctic regions. Palaeogeography, Palaeoclimatology, Palaeoecology 145, 95-117.

Bauch H.A., Erlenkeuser H., Grootes P.M. \& Jouzel J. 1996. Implications of stratigraphic and paleoclimatic records of the last interglaciation from the Nordic seas. Quaternary Research 46, 260-269.

Bauch H.A., Erlenkeuser H., Jung S.J.A. \& Thiede J. 2000. Surface and deep water changes in the subpolar North Atlantic during Termination II and the last interglaciation. Paleoceanography 15, 76-84.
Bauch H.A., Erlenkeuser H., Spielhagen R.F., Struck U., Matthiessen J., Thiede J. \& Heinemeier J. 2001. A multiproxy reconstruction of the evolution of deep and surface waters in the subarctic Nordic seas over the last 30,000 years. Quaternary Science Reviews 20, 659-678.

Bauch H.A. \& Kandiano E.S. 2007. Evidence for early warming and cooling in North Atlantic surface waters during the last interglacial. Paleoceanography 22, PA1201, doi: 10.1029/2005 PA001252.

Bé A.W. \& Tolderlund D.S. 1971. Distribution and ecology of living planktonic foraminifera in surface waters of the Atlantic and Indian oceans. In B.M. Funnel \& W.R. Riedel (eds.): The micropaleontology of oceans. Pp. 105-149. Cambridge: Cambridge University Press.

Berger A. 1978. Long-term variations of daily insolation and Quaternary climatic changes. Journal of the Atmospheric Sciences 35, 2362-2367.

Calvo E., Grimalt J. \& Jansen E. 2002. High resolution U37K sea surface temperature reconstruction in the Norwegian Sea during the Holocene. Quaternary Science Reviews 21, 1385-1394.

Carstens J. 1991. Verteilung planktischer Foraminiferen in der Wassersäule. (Distribution of planktic foraminifers in the water column.) In J. Thiede \& G. Hempel (eds.) Die Expedition ARKTIS-VII/I mit FS "Polarstern" 1990. (The ARKTIS-VII/1 expedition with the RV Polarstern in 1990.) Berichte zur Polarforschung 80, 60-62.

Carstens J., Hebbeln D. \& Wefer, G. 1997. Distribution of planktic foraminifera at the ice margin in the Arctic (Fram Strait). Marine Micropaleontology 29, 257-269.

Chapman M.R. \& Shackleton N.J. 1999. Global ice-volume fluctuations, North Atlantic ice-rafting events, and deep-ocean circulation changes between 130 and 70 Ka. Geology 27, 795-798.

Cortijo E., Duplessy J.-C., Labeyrie L., Leclaire H., Duprat J. \& van Weering T.C.E. 1994. Eemian cooling in the Norwegian Sea and North Atlantic ocean preceding continental ice-sheet growth. Nature 372, 446-449.

Cuffey K.M. \& Marshall S.J. 2000. Substantial contribution to sea-level rise during the last interglacial from the Greenland ice sheet. Nature 404, 591-594.

Dansgaard W., Johnsen S.J., Clausen H.B., Dahl-Jensen D., Gundestrup N.S., Hammer C.U., Hvidberg C.S., Steffensen J.P., Sveinbjörnsdottir A.E., Jouzel J. \& Bond G. 1993. Evidence for general instability of past climate from a 250-kyr ice-core record. Nature 364, 218-220.

Didié C. \& Bauch H.A. 2000. Species composition and glacial-interglacial variations in the ostracode fauna in the northeast Atlantic during the past 200,000 years. Marine Micropaleontology 40, 105-129.

Dokken T.D. \& Jansen E. 1999. Rapid changes in the mechanism of ocean convection during the last glacial period. Nature 401, 458-461.

Eynaud F., Turon J.-L. \& Duprat J. 2004. Comparison of the Holocene and Eemian palaeoenvironments in the South Icelandic Basin: dinoflagellate cysts as proxies for the 
North Atlantic surface circulation. Review of Palaeobotany and Palynology 128, 55-79.

Fairbanks R.G., Mortlock R.A., Chiu T.-C., Cao L., Kaplan A., Guilderson T.P., Fairbanks T.W., Bloom A.L., Grootes P.M. \& Nadeau M.-J. 2005. Radiocarbon calibration curve spanning 0 to 50000 years BP based on paired 230Th/ 234U/238U and 14C dates on pristine corals. Quaternary Science Reviews 24, 1781-1796.

Fronval T. \& Jansen E. 1996. Rapid changes in ocean circulation and heat flux in the Nordic seas during the last interglacial period. Nature 383, 806-810.

Fronval T. \& Jansen E. 1997. Eemian and early Weichselian (140-60 ka) paleoceanography and paleoclimate in the Nordic seas with comparisons to Holocene conditions. Paleoceanography 12, 443-462.

Fronval T., Jansen E., Haflidason H. \& Sejrup H.-P. 1998. Variability in surface and deep water conditions in the Nordic seas during the last interglacial period. Quaternary Science Reviews 17, 963-985.

Funder S., Demidov I. \& Yelovicheva Y. 2002. Hydrography and mollusc faunas of the Baltic and the White Sea-North Sea seaway in the Eemian. Palaeogeography,

Palaeoclimatology, Palaeoecology 184, 275-304.

Gouzy A., Malaizé B., Pujol C. \& Charlier K. 2004. Climatic "pause" during Termination II identified in shallow and intermediate waters off the Iberian margin. Quaternary Science Reviews 23, 1523-1528.

Grootes P.M., Stuiver M., White J.W.C., Johnsen S. \& Jouzel J. 1993. Comparison of oxygen isotope records from the GISP2 and GRIP Greenland ice cores. Nature 366, 552-554.

Haake F.W. \& Pflaumann U. 1989. Late Pleistocene foraminiferal stratigraphy on the Vøring Plateau, Norwegian Sea. Boreas 18, 343-356.

Hald M., Andersson C., Ebbesen H., Jansen E., Klitgaard-Kristensen D., Risebrobakken B., Salomonsen G.R., Sarnthein M., Sejrup H.P. \& Telford R.J. 2007. Variations in temperature and extent of Atlantic Water in the northern North Atlantic during the Holocene. Quaternary Science Reviews 26, 3423-3440.

Hald M., Ebbesen H., Forwick M., Godtliebsen F., Khomenko L., Korsun S., Olsen L. \& Vorren T.O. 2004. Holocene paleoceanography and glacial history of the west Spitsbergen area, Euro-Arctic margin. Quaternary Science Reviews 23, 2075-2088.

Hebbeln D., Dokken T., Andersen E.S., Hald M. \& Elverhoi A. 1994. Moisture supply for northern ice-sheet growth during the Last Glacial Maximum. Nature 370, 357-360.

Hillaire-Marcel C., de Vernal A., Bilodeau G. \& Weaver A.J. 2001. Absence of deep-water formation in the Labrador Sea during the last interglacial period. Nature 410, 1073-1077.

Imbrie J., Boyle E.A., Clemens S.C., Duffy A., Howard W.R., Kukla G., Kutzbach J., Martinson D.G., McIntyre A., Mix A.C., Molfino B., Morley J.J., Peterson L.C., Pisias N.G., Prell W.L., Raymo M.E., Shackleton N.J. \& Toggweiler J.R. 1992. On the structure and the origin of major glaciation cycles: 1. Linear responses to Milankovitch forcing. Paleoceanography 7, 701-738. Johannessen T., Jansen E., Flatøy A. \& Ravelo A. 1994. The relationship between surface water masses, oceanographic fronts and paleoclimatic proxies in surface sediments of the Greenland, Iceland, Norwegian seas. In R. Zahn et al. (eds.) Carbon cycling in the glacial ocean: constraints on the ocean's role in global change. Pp. 61-85. Berlin: Springer.

Jung W.Y. \& Vogt P.R. 2004. Effects of bottom water warming and sea level rise on Holocene hydrate dissociation and mass wasting along the Norwegian-Barents continental margin. Journal of Geophysical Research-Solid Earth 109(B6), doi: 10.1029/ 2003JB002738.

Kandiano E.S. \& Bauch H.A. 2002. A case study on the application of different planktic foraminiferal size fractions for interpreting late Quaternary paleoceanographic changes in the polar North Atlantic. Journal of Foraminiferal Research 32, 245-251.

Kandiano E.S., Bauch H.A. \& Müller A. 2004. Sea surface temperature variability in the North Atlantic during the last two glacial-interglacial cycles: comparison of faunal, oxygen isotopic and $\mathrm{Mg} / \mathrm{Ca}$-derived records.

Palaeogeography, Palaeoclimatology, Palaeoecology 204, 145-164.

Kellogg T.B. 1980. Paleoclimatology and paleoceanography of the Norwegian and Greenland seas: glacial-interglacial contrasts. Boreas 9, 115-137.

Koç N., Jansen E. \& Haflidason H. 1993. Paleoceanograhic reconstructions of surface ocean conditions in the Greenland, Iceland and Norwegian seas through the last 14 ka based on diatoms. Quaternary Science Reviews 12, 115-140.

Koerner R.M. 1989. Ice core evidence for extensive melting of the Greenland ice sheet in the last interglacial. Science 244, 964-968.

Kukla G.J. \& Went E. (eds.) 1992. Start of a glacial. Proceedings of the NATO Advanced Research Workshop on Correlating Records of the Past. NATO ASI Series 1. Vol. 3. Heidelberg: Springer.

Lambeck K., Purcell A., Funder S., Kjær K., Larsen E. \& Möller P. 2006. Constraints on the Late Saalian to early Middle Weichselian ice sheet of Eurasia from field data and rebound modelling. Boreas 35, 539-575.

Lehman S.J., Sachs J.P., Crotwell A.M., Keigwin L.D. \& Boyle E.A. 2002. Relation of subtropical Atlantic temperature, high-latitude ice rafting, deep water formation, and European climate 130 000-60 000 years ago. Quaternary Science Reviews 21, 1917-1924.

Martinson D.G., Pisias N.G., Hays J.D., Imbrie J., Moore T.C. \& Shackleton N.J. 1987. Age dating and the orbital theory of the ice ages-development of a high-resolution 0 to 300,000 years chronostratigraphy. Quaternary Research 27, $1-29$.

Matthiessen J. \& Knies J. 2001. Dinoflagellate cyst evidence for warm interglacial conditions at the northern Barents 
Sea margin during marine oxygen isotope stage 5. Journal of Quaternary Science 16, 727-737.

McManus J., Bond G., Broecker W., Johnsen S., Labeyrie L. \& Higgins S. 1994. High-resolution climate records from the North Atlantic during the last interglacial. Nature 371, 326-329.

Montoya M., Crowley T.J. \& von Storch H. 1998.

Temperatures at the last interglacial simulated by a coupled ocean-atmosphere climate model. Paleoceanography 13, 170-177.

Müller U.C. \& Kukla G.J. 2004. North Atlantic Current and European environments during the declining stage of the last interglacial. Geology 32, 1009-1012.

Nesje A. \& Kvamme M. 1991. Holocene glacier and climate variations in western Norway: evidence for early Holocene glacier demise and multiple Neoglacial events. Geology 19 , 610-612.

Nørgaard-Pedersen N., Mikkelsen N., Lassen S.J., Kristoffersen Y. \& Sheldon E. 2007. Reduced sea ice concentrations in the Arctic Ocean during the last interglacial period revealed by sediment cores off northern Greenland. Paleoceanography 22, PA1218, doi: 10.1029/ 2006PA001283.

Oppo D.W., Horowitz M. \& Lehman S.J. 1997. Marine core evidence for reduced deep water production during Termination II followed by a relatively stable substage 5e (Eemian). Paleoceanography 12, 51-63.

Otto-Bliesner B.L., Marshall S.J., Overpeck J.T., Miller G.H. \& Hu A. 2006. Simulating Arctic climate warmth and icefield retreat in the last interglaciation. Science 311, 1751-1753.

Overpeck J.T., Otto-Bliesner B.L., Miller G.H., Muhs D.R., Alley R.B. \& Kiehl J.T. 2005. Paleoclimatic evidence for future ice-sheet instability and rapid sea-level rise. Science 311, 1747-1750.

Pflaumann U. 1988. Plankton-Foraminiferen in der Sedimentoberfläche. (Planktic foraminifers in surface sediments.) Berichte aus dem Sonderforschungsbereich 313, 175-177. Kiel: University of Kiel.

Pflaumann U., Duprat J., Pujol C. \& Labeyrie L.D. 1996. SIMMAX, a modern analog technique to deduce Atlantic sea surface temperatures from planktonic foraminifera in deep-sea sediments. Paleoceanography 11, 15-35.

Rasmussen T.L., Balbon E., Thomsen E., Labeyrie L. \& van Weering T.C.E. 1999. Climate records and changes in deep outflow from the Norwegian Sea $\sim 150-55$ ka. Terra Nova $11,61-66$.

Rasmussen T.L., Thomsen E., Kuijpers A. \& Wastegård S. 2003. Late warming and early cooling of the sea surface in the Nordic seas during MIS 5e (Eemian interglacial). Quaternary Science Reviews 22, 809-821.

Rasmussen T.L., Thomsen E., van Weering T.C.E. \& Labeyrie L. 1996. Rapid changes in surface and deep waters at the Faeroe Margin during the last 58,000 years. Paleoceanography 11, 757-771.

Riesebrobakken B., Balbon E., Dokken T., Jansen E., Kissel C., Labeyrie L., Richter T. \& Senneset L. 2006.
The penultimate deglaciation: high-resolution paleoceanographic evidence from a north-south transect along the eastern Nordic seas. Earth and Planetary Science Letters 241, 505-516.

Riesebrobakken B., Dokken T., Otterå O.H., Jansen E., Gao Y. \& Drange H. 2007. Inception of the northern European ice sheet due to contrasting ocean and insolation forcing. Quaternary Research 67, 128-135.

Riesebrobakken B., Jansen E., Andersson C., Mjelde E. \& Hevrøy K. 2003. A high-resolution study of Holocene paleoclimatic and paleoceanographic changes in the Nordic seas. Paleoceanography 18, 1017, doi: 10.1029/ 2002 PA000764.

Sarnthein M. \& Tiedemann R. 1990. Younger Dryas-style cooling events at glacial terminations I-VI at ODP-Site 658: associated benthic $\delta^{13} \mathrm{C}$ anomalies constrain meltwater hypothesis. Paleoceanography 5, 1041-1055.

Sarnthein M., van Kreveld S., Erlenkeuser H., Grootes P.M., Kucera M., Pflaumann U. \& Schulz M. 2003.

Centennial-to-millennial-scale periodicities of Holocene climate and sediment injections off the western Barents shelf, $75^{\circ} \mathrm{N}$. Boreas 32, 447-461.

Schröder-Ritzrau A., Andruleit H., Jensen S., Samtleben C., Schäfer P., Matthiessen J., Hass H.C., Kohly A. \& Thiede J. 2001. Distribution, export and alteration of fossilizable plankton in the Nordic seas. In P. Schäfer et al. (eds.): The northern Atlantic: a changing environment. Pp. 81-104. Berlin: Springer.

Seidenkrantz M.-S. \& Knudsen K.L. 1997. Eemian climatic and hydrographical instability on a marine shelf in Northern Denmark. Quaternary Research 47, 218-234.

Shaffer G., Olsen S.M. \& Bjerrum C.J. 2004. Ocean subsurface warming as a mechanism for coupling Dansgaard-Oeschger climate cycles and ice-rafting events. Geophysical Research Letters 31, L24202, doi: 10.1029/ 2004GL020968.

Siddall M., Bard E., Rohling E.J. \& Hemleben C. 2006. Sea-level reversal during Termination II. Geology 34, $817-820$

Simstich J. 1999. Die ozeanische Deckschicht des Europäischen Nordmeers im Abbild stabiler Isotope von Kalkgehäusen unterschiedlicher Planktonforaminiferenarten. (Variations in the oceanic surface layer of the Nordic seas: the stable isotope record of polar and subpolar planktonic foraminifera.) Berichte-Reports, Institut für Geowissenschaften, Universität Kiel 2. Kiel: Institute of Geosciences, University of Kiel.

Van Nieuwenhove N. \& Bauch H.A. 2008. Last interglacial (M15 5e) surface water conditions at the Vøring Plateau (Norwegian Sea), based on dinoflagellate cysts. Polar Research 27, 175-186 (this issue).

Van Nieuwenhove N., Bauch H.A. \& Matthiessen J. 2008. Last interglacial surface water conditions in the eastern Nordic seas inferred from dinocyst and foraminiferal assemblages. Marine Micropaleontology 66, 247-263.

Veum T., Jansen E., Arnold M., Beyer I. \& Duplessy J.-C. 1992. Water mass exchange between the North Atlantic 
and the Norwegian Sea during the past 28,000 years. Nature 356, 783-785.

Vogelsang E. 1990. Paläo-Ozeanographie des Europäischen Nordmeeres anhand stabiler Kohlenstoff- und Sauerstoffisotope. (Paleoceanography of the Nordic seas on the basis of stable carbon and oxygen isotopes.) Berichte aus dem Sonderforschungsbereich 313. Kiel: University of Kiel.
Winn K., Glos R., Averdieck F.R. \& Erlenkeuser H. 2000. On the age of the marine Eem in northwestern Germany. Geologos 5, 41-56.

Winograd I.J., Coplen T.B., Landwehr J.M., Riggs A.C., Ludwig K.R., Szabo B.J., Kolesar P.T. \& Revesz M. 1992. Continuous 500 000-year climate record from vein calcite in Devils Hole, Nevada. Science 258, 255-260. 